\title{
In Vitro Antioxidant and Antiproliferative Efficacy of Abrus Precatorius Seed Extracts on Hep2c Cells and its Inhibitory Efficacy with Receptors of Cervical Carcinoma
}

\author{
Amritpal Kaur \\ Amity University \\ Yash Sharma \\ Amity University \\ Kamran Waidha \\ Defense Institute of High-Altitude Research, DRDO \\ Madhumita P Ghosh \\ Amity University \\ Anoop Kumar \\ National Institute of Biological \\ Kumud Bala ( $\sim$ kbala@amity.edu ) \\ Amity University
}

\section{Research Article}

Keywords: Abrus precatorius, HPLC, Antioxidant, Anticancer, Cervical Cancer Cell Line

Posted Date: January 3rd, 2022

DOI: https://doi.org/10.21203/rs.3.rs-1040550/v2

License: (c) (i) This work is licensed under a Creative Commons Attribution 4.0 International License. Read Full License

Version of Record: A version of this preprint was published at Scientific Reports on June 17th, 2022. See the published version at https://doi.org/10.1038/s41598-022-13976-7. 


\section{Abstract}

Abrus precatorius is a widely distributed tropical medicinal plant with several therapeutic properties, however its seed extract has not been studied against cervical cancer ( $\mathrm{CaCx}$ ) till date. Herein, we have assessed the antioxidant and antiproliferative properties of $A$. precatorius seed extracts (ethyl acetate and $70 \%$ ethanol) prepared from different extraction methods (Soxhlet and maceration) against human cervix carcinoma cells (Hep2C). We observed a significantly higher total flavonoid content of APE (sox) i.e.,112.7 $\pm 0.127 \mathrm{mg}$ Quercetin Equivalent/g of extract than others; total phenolic content of APA (mac) seed extract was higher i.e.,108.53 $\pm 0.089 \mathrm{mg}$ Quercetin Equivalent/g of extract and total tannin content of APA (sox) was higher i.e., $98.98 \pm 0.011 \mathrm{mg}$ tannic acid equivalents/g of extract. In addition, tannic acid, rutin and piperine were identified in extracts by HPLC. Furthermore, APA (sox) exhibited the highest radical scavenging activity with an IC50 value of $14.49 \pm 0.93 \mu \mathrm{g} / \mathrm{ml}$. APE (mac) showed the most significant antiproliferative activity with IC50 value of $85.90 \pm 0.93 \mu \mathrm{g} / \mathrm{mL}$ against Hep2c cells. SOD and GST activity was observed as highest in the APA(Mac) extract whereas the catalase activity and GSH content was maximum in the $\mathrm{APE}(\mathrm{Mac})$ extract. Further, the MDA content was observed to be the least in APE(Mac) extracts. Docking results suggested maximum binding energy between tannic acid and Her2 receptor compared to doxorubicin (standard). This study provides evidence that $A$. precatorius seed extracts possess promising bioactive compounds with probable anticancer and antioxidant properties against $\mathrm{CaCx}$ which might be utilized as a possible herbal remedy aimed at restricting tumor growth.

\section{Introduction}

Cancer is one of the major causes of mortality in both men and women worldwide and its research has garnered attention from the scientific fraternity all across the globe. Considering the global burden of gynecological cancers, cervical cancer ( $\mathrm{CaCx}$ ) among them ranks as the fourth most common cancer with nearly 5,70,000 new reported cases and 3,11,000 deaths ${ }^{1}$. Despite effective screening measures and treatment modalities, CaCx continues to hold the banner of the leading cause of cancer related mortality among women ${ }^{2}$. Therefore, the development of novel therapeutic drugs with increased efficiency is warranted. Receptors like Glucocorticoids (GCR), Human epidermal growth factor receptor 2 (HER2) and Beta-hexosaminidase subunit beta (HEXB) are reported to be associated with progression of $\mathrm{CaCx}$ and have been established as promising therapeutic candidates as corroborated by in-silico analysis $^{3-5}$. Out of the 1881 new chemical entities, that had been approved as drugs between 1981 and 2019 , the purely synthetic compounds amount for only $24.6 \%$, while a majority of the new drugs were derived from medicinal plants ${ }^{6}$. Herbal plants have made important contributions to the development of anticancer drugs. Numerous natural substances are recognized to be anti-oxidants, cancer preventive agents or even antitumor agents such as paclitaxel 7.

Abrus precatorius L. (Fabaceae) is a plant that spans tropical and subtropical parts of the world. Lowly elevated, dry regions are conducive for its growth. Known for its medicinal value, its leaves, roots and seeds are often exploited for anti-helminthic, anti-diarrhoeal, neuroprotective, anti-dipression, anti-fertility, anti-cataract, anti-arthritic, anti-allergic and anti-emetic purposes. Abrus derived lectins have been widely used in treating various cancers ${ }^{8}$. Evidence advocates that the seeds of this medicinal herb are effective in treating diabetes and chronic nephritis. Moreover, $A$. precatorius leaves possess a sweetness quotient equivalent to sucrose and are therefore used to sweeten foods in West tropical Africa ${ }^{9}$.

The main aim of the study was to prepare $A$. precatorius seed extracts using soxhlet and maceration methods to identify various phytochemical compounds and evaluate their abilities to function as antioxidant and in-vitro 
assessment as anti-proliferative agent in human cervix carcinoma (Hep2c) cells.

\section{Results}

\section{Molecular Identification}

The amplified DNA was purified and sequenced using rbcLa-forward and rbcLa-reverse primers used for PCR. NCBI BLAST_N program was used to compare the nucleotide sequence available in Gen Bank. Sequence analysis confirmed the sample showed $98.8 \%$ identity having $81 \%$ query cover with previous reported sequences of $A$. precatorius (NC_047402.1).

\section{Quantification of phytochemicals constituents}

Total flavonoid content in seed extracts of $A$. precatorius were obtained from standard calibration curve $y=0.010 \mathrm{x}, \mathrm{r}^{2}$ $=0.984$, where $x$ is the concentration and $y$ are the absorbance of quercetin $(\mu \mathrm{g} / \mathrm{ml})$ expressed in mg quercetin equivalents/ $\mathrm{g}$ of Extract as shown in Figure 1. APE (sox) extract demonstrated high flavonoid content i.e., $112.7 \pm 0.127 \mathrm{mg}$ quercetin equivalents/g of extract, while APE (mac) extract showed $77.57 \pm 0.002 \mathrm{mg}$ quercetin equivalents/ g of extract. Moreover, APA (mac) extract exhibited $41.85 \pm 0.017 \mathrm{mg}$ quercetin equivalents/ $\mathrm{g}$ of extract while APA (sox) extract only showed 4.8 \pm 0.014017 mg quercetin equivalents/ g of extract (Table1) (Graph 1, Supplementary).

Furthermore, the phenolic content in seed extracts of $A$. precatorius as obtained from standard calibration curve $y=$ $0.015 x, r^{2}=0.998$, where $x$ is the concentration and $y$ are the absorbance of is the absorbance of quercetin ( $\left.\mu \mathrm{g} / \mathrm{ml}\right)$ expressed in mg quercetin equivalents/ $\mathrm{g}$ of extract as shown in Figure 1. Phenolic content of APA (mac) and APA (sox) seed extracts were found to be nearer to each other i.e., $108.53 \pm 0.089 \mathrm{mg}$ quercetin equivalents/ g of extract and $103.98 \pm 0.036 \mathrm{mg}$ quercetin equivalents/ g of extract, respectively. Whereas, APE (sox) and APE (mac) seed extract showed less amount of QE (quercetin equivalents) at $28.40 \pm 0.157 \mathrm{mg} / \mathrm{g}$ of extract and $14.34 \pm 0.045 \mathrm{mg} / \mathrm{g}$ of extract, respectively (Table1) (Graph 2, Supplementary).

Total tannins content in seed extracts of $A$. precatorius as obtained from standard calibration curve $y=0.0143 x, r=$ 0.9989 , where $x$ is the concentration and $y$ are the absorbance of is the absorbance of quercetin $(\mu \mathrm{g} / \mathrm{ml})$ expressed in mg tannic acid equivalents/g of extract as shown in Figure 1. The results indicated that APA (sox) seed extract contained $98.98 \pm 0.011 \mathrm{mg}$ tannic acid equivalents / $\mathrm{g}$ of extract, while tannic acid equivalents value of APA (mac) seed extract was $89.35 \pm 0.090 \mathrm{mg} / \mathrm{g}$ of extract Whereas, APE (sox) and APE (mac) seed extracts showed less amount of tannic acid equivalents at $26.35 \pm 0.045 \mathrm{mg} / \mathrm{g}$ of extract and $17.07 \pm 0.052 \mathrm{mg} / \mathrm{g}$ of extract, respectively (Graph 3 , Supplementary).

Table 1: Quantitative estimation of phytochemicals of different seed extracts of $A$. precatorius. 


\begin{tabular}{|lllll|}
\hline Phytochemical Quantification & $\begin{array}{l}\text { Ethyl acetate } \\
\text { extract } \\
\text { (Maceration } \\
\text { Method) }\end{array}$ & $\begin{array}{l}\text { Ethyl acetate } \\
\text { extract } \\
\text { (Soxhlet } \\
\text { Method) }\end{array}$ & $\begin{array}{l}\text { 70\% Ethanol } \\
\text { extract } \\
\text { (Soxhlet } \\
\text { Method) }\end{array}$ & $\begin{array}{l}\text { 70\% Ethanol } \\
\text { extract } \\
\text { (Maceration } \\
\text { Method) }\end{array}$ \\
\hline $\begin{array}{l}\text { Total Flavonoid Content (mg Quercetin } \\
\text { Equivalents /g of extract) }\end{array}$ & $77.57 \pm 0.002$ & $112.7 \pm 0.127$ & $41.85 \pm 0.017$ & $4.8 \pm 0.014$ \\
\hline $\begin{array}{l}\text { Total Phenolic Content (mg Quercetin } \\
\text { Equivalents /g of extract }\end{array}$ & $14.34 \pm 0.045$ & $28.40 \pm 0.157$ & $103.98 \pm$ & $108.53 \pm 0.089$ \\
\hline $\begin{array}{l}\text { Total Tannins Content (mg T.A Equivalents } \\
\text { /g of extract) }\end{array}$ & $17.07 \pm 0.052$ & $26.35 \pm 0.045$ & $98.98 \pm 0.011$ & $89.35 \pm 0.090$ \\
\hline
\end{tabular}

\section{Antioxidant Assay}

The antioxidant potential of $A$. precatorius seed extracts were analyzed by DPPH free radical scavenging assay. Quercetin (standard) and the different seed extracts showed variable antioxidant properties. APA (sox) and APA (mac) seed extracts exhibited significantly $(\mathrm{p}<0.00005)$ high DPPH free radical scavenging in a dose-dependent manner with concentration $(3-21 \mu \mathrm{g} / \mathrm{ml}$ ) (Figure. $2 \mathrm{a})$ and $(23-37 \mu \mathrm{g} / \mathrm{ml}$ ) (Figure. $2 \mathrm{~b}$ ). The IC50 value of Quercetin was $14.49 \pm$ $0.93 \mu \mathrm{g} / \mathrm{mL}$. The higher IC50 value indicates lower radical scavenging activity. The IC50 value of APA (sox) and APA (mac)seed extracts were close to standard, i.e., $14.49 \pm 0.93 \mu \mathrm{g} / \mathrm{ml}$ and $23.8 \pm 0.68 \mu \mathrm{g} / \mathrm{ml}$, Figure. 2 a \& b) respectively Whereas, APE (sox) and APE (mac) seed extracts showing least DPPH free radical scavenging in a dose-dependent manner with concentration $(150-350 \mu \mathrm{g} / \mathrm{ml})$ (Figure. $2 \mathrm{c}$ ), and (150-650 $\mu \mathrm{g} / \mathrm{ml})$ (Figure. $2 \mathrm{~d})$, with an IC50 value $222.51 \pm 3.15 \mu \mathrm{g} / \mathrm{ml}$ and $482.76 \pm 6.96 \mu \mathrm{g} / \mathrm{ml}$, respectively (Figure. 2).

Antioxidant capacity was also quantified by FRAP assay. FRAP values were obtained against standard calibration curve of $\mathrm{FeSO}_{4}$ at concentration between 100-1000 $\mu \mathrm{M}$ i.e., $\mathrm{y}=0.001 \mathrm{x}, \mathrm{r}^{2}=0.919$ where $\mathrm{x}$ is the concentration and $\mathrm{y}$ are the absorbance that indicates the e capacity to reduce ferric (III) iron to ferrous (II) iron. APA (mac) and APA (sox) have exhibited reducing capacity value105060.2 $\pm 0.086 \mathrm{mM} \mathrm{Fe}(\mathrm{II}) / \mathrm{g}$ dry weight of seed extract as and $95841 \pm 0.126$ $\mathrm{mM} \mathrm{Fe}(\mathrm{II}) / \mathrm{g}$ dry weight of seed extract, respectively. APE (sox) and APE (mac) have revealed reducing capacity value $5849.39 \pm 0.014 \mathrm{mM}$ Fe (II)/g dry weight of seed extract and $6216.59 \pm 0.005 \mathrm{mM} \mathrm{Fe}$ (II)/ g dry weight of seed extract, respectively (Graph 4, Supplementary).

\section{HPLC analysis}

Phytochemicals like polyphenolic flavonoids (rutin), tannins (tannic acid), and alkaloids (piperine) were determined in the seed extracts of $A$. precatorius prepared from different extraction method. The results show that the retention times of rutin, tannic acid and piperine were RT3.817, RT3.093 and RT14.847, respectively as shown in Figure 3. Rutin and tannic acid were identified in APA (sox), APA (mac), APE (sox), and APE (mac) seed extracts and their retention time were similar to the standards. Piperine was also identified but showed very less peaks in APA (mac), APE (sox) and APE (mac). No peak of piperine was identified in APA (sox) seed extract (Figure. 3). This indicates the presence of both the polyphenolic flavonoids and tannins in the seed extracts of $A$ precatorius prepared obtained from different extraction methods.

\section{Cytotoxic activity of seed extracts against Hep2C Cell line}


A. precatorius seed extracts were evaluated for its antiproliferative potential using MTT assay. Doxorubicin (standard) and the different seed extracts showed variable antiproliferative activity. IC50 values were also determined, lower IC50 values indicating higher the antiproliferative activity. As illustrated in Figure. 4 c, APE (mac) seed extract exhibited highly significant $(p<0.005)$ cytotoxicity against Hep2C cells in a dose-dependent manner with concentration $(50-200$ $\mu \mathrm{g} / \mathrm{ml}$ ) with an IC50 value $85.90 \pm 0.93 \mu \mathrm{g} / \mathrm{ml}$ as compared to the APE (sox) seed extract with an IC50 value $142.80 \pm 10.80 \mu \mathrm{g} / \mathrm{ml}$. Moreover, APA (sox) and APA (mac) seed extracts showed less cytotoxicity against Hep2C cells as compared to APE seed extracts with an IC50 values $374.16 \pm 20.53 \mu \mathrm{g} / \mathrm{ml}$ and $430 \mu \mathrm{g} / \mathrm{ml}$, (Figure. 4 b) respectively. Comparatively, Doxorubicin, an anticancer drug used in this study as a positive control, demonstrated IC50 value 1.84 $\mu \mathrm{g} / \mathrm{ml}$ in a dose-dependent manner with concentration $(5-15 \mu \mathrm{g} / \mathrm{ml}$ ) (Figure. $4 \mathrm{a})$. Comparative statistical significance between the extracts (APA (sox), APA (mac), APE (sox), APE (mac) and doxorubicin (Figure. 4 d). Further, upon observation under the microscope, the Hep2c cells after exposure with standard (doxorubicin), APE and APA seed extracts displayed reduced size and abnormally shrunken, compared to untreated cells (Figure. 4 e-j).

\section{Antioxidant Enzymes Activity Assay on Hep2C cells}

The antioxidant activity of each extract was observed in the treated Hep2C cells with IC50 specific values to determine the intercellular free radical scavenging ability. From Table. 2., we can observe that the highest SOD enzymatic activity in APA (Mac) i.e., $4.6 \pm 0.08 \mathrm{U} / \mathrm{min} / \mathrm{mg}$ of protein at an IC50 of $430.08 \pm 20.46 \mu \mathrm{g} / \mathrm{ml}$ compared to the control cells i.e., $2.74 \pm 0.08 \mathrm{U} / \mathrm{min} / \mathrm{mg}$ of protein and other extracts. Similarly, the catalase enzyme activity was observed to be the highest in the APE (Mac) extract with $28.37 \pm 0.32 \mu \mathrm{moles} / \mathrm{min} / \mathrm{mg}$ of protein at IC50 of 85.90 $\pm 0.93 \mu \mathrm{g} / \mathrm{ml}$ compared to the control i.e., $8.49 \pm 0.08 \mu \mathrm{moles} / \mathrm{min} / \mathrm{mg}$ of protein and other extracts. The non-enzyme content such as glutathione and lipid peroxidation were also quantified in the cells. The GST activity in the Hep2C cells after treating with the APA(Mac) extract was observed to be the highest $(42.16 \pm 0.55 \mu \mathrm{moles} / \mathrm{min} / \mathrm{mg}$ of protein, IC50:430.08 \pm 20.46$)$ compared to the control $(28.5 \pm 0.31 \mu \mathrm{moles} / \mathrm{min} / \mathrm{mg}$ of protein) and other extracts. Similarly, we found that APE (Mac) treated cells with IC50: $85.90 \pm 0.93 \mu \mathrm{g} / \mathrm{ml}$ (IC50) showed maximum glutathione content of $22,438 \pm 456.25 \mu \mathrm{g} / \mathrm{mg}$ of protein compared to the control cells i.e., $18,397 \pm 57.42 \mu \mathrm{g} / \mathrm{mg}$ of protein and other extracts. Hep2C cells showed a marked decrease in the MDA content $(0.041 \pm 0.0009 \mu \mathrm{g} / \mathrm{mg}$ of protein) upon exposure to $\operatorname{APE}(\mathrm{Mac})$ with IC50 of $85.90 \pm 0.93 \mu \mathrm{g} / \mathrm{ml}$ rather than the extracts and control cells i.e., $0.084 \pm 0.002 \mu \mathrm{g} / \mathrm{mg}$ of protein (Figure. 5).

Table. 2. Enzymatic and Non-enzyme content in Hep2C cells upon treatment with different extracts

\begin{tabular}{|c|c|c|c|c|c|c|}
\hline Extract & IC50 ( $(\mu \mathrm{g} / \mathrm{ml})$ & $\begin{array}{l}\text { SOD } \\
\text { (Unit/ } \\
\mathrm{min} / \mathrm{mg} \\
\text { of } \\
\text { protein) }\end{array}$ & $\begin{array}{l}\text { Catalase } \\
\text { ( } \text { moles/min } / \mathrm{mg} \\
\text { of protein) }\end{array}$ & $\begin{array}{l}\text { GST } \\
\text { ( } \mu \text { moles/ } \\
\text { min/mg of } \\
\text { protein) }\end{array}$ & $\begin{array}{l}\text { GSH } \\
(\mu \mathrm{g} / \mathrm{mg} \text { of } \\
\text { protein) }\end{array}$ & $\begin{array}{l}\text { MDA }(\mu \mathrm{g} / \mathrm{mg} \\
\text { of protein) }\end{array}$ \\
\hline Control & - & $2.74 \pm 0.08$ & $8.49 \pm 0.08$ & $28.5 \pm 0.31$ & $18,397.1 \pm 57.42$ & $0.084 \pm 0.002$ \\
\hline APA(Mac) & $\begin{array}{l}430.08 \\
\pm 20.46\end{array}$ & $4.6 \pm 0.08$ & $25.30 \pm 0.08$ & $42.16 \pm 0.55$ & $20,615.8 \pm 93.18$ & $0.064 \pm 0.001$ \\
\hline APA(Sox) & $374.16 \pm 20.53$ & $4.05 \pm 0.05$ & $23.15 \pm 0.05$ & $38.62 \pm 0.79$ & $19,117.3 \pm 33.42$ & $0.079 \pm 0.0006$ \\
\hline APE(Mac) & $85.90 \pm 0.93$ & $3.92 \pm 0.28$ & $28.37 \pm 0.32$ & $33.55 \pm 0.55$ & $22,438.8 \pm 456.25$ & $0.041 \pm 0.0009$ \\
\hline APE(Sox) & $142.80 \pm 10.80$ & $3.05 \pm 0.06$ & $12.57 \pm 0.06$ & $29.37 \pm 0.38$ & $19,544.6 \pm 33.42$ & $0.072 \pm 0.0008$ \\
\hline
\end{tabular}




\section{Molecular Docking Analysis}

Molecules characterized from HPLC were identified and docked to cervical cancer specific targets such as Human Epidermal Growth Factor Receptor 2 (HER2), Hexosaminidase Subunit Beta (HEXB) and Glucocorticoid receptor (GCR). Molecular docking was performed followed by MM-GBSA refinement using Doxorubicin as a control molecule. The results are given in Table 3. It was found from the study that tannic acid has scored the highest docking score of $-112.53 \mathrm{Kcal} / \mathrm{mol}$ with HER2 (Figure.6 b). Piperine revealed a similar docking score of $-42.11 \mathrm{Kcal} / \mathrm{mol}$ and -42.15 $\mathrm{Kcal} / \mathrm{mol}$ for Glucocorticoid receptor and HER2 respectively (Figure. $6 \mathrm{c}$ ). However, piperine resulted in a lower dock score of $-29.74 \mathrm{Kcal} / \mathrm{mol}$ for HEXB. In the binding pocket of HER2, piperine forms one conventional and three aromatic hydrogen bonds. The Hydrogen bond formation occurs between the HN of Leu436 and 0 of 1,3-dioxolane ring of piperine (1.81 A). Aromatic hydrogen bonds are formed with Gly28, Leu 436, and Arg434. Similarly, in the active pocket of GCR Piperine forms a single hydrogen bond with THR739. Rutin is a flavonoid that can be obtained by the glycosylation of quercetin. The docking score of rutin varied from $-48.21 \mathrm{Kcal} / \mathrm{mol}$ to $-35.02 \mathrm{Kcal} / \mathrm{mol}$. The rutin was found to have a higher binding affinity towards the HER2 receptor by forming 7 conventional hydrogen bonds within the active site. The interaction was mostly found due to the presence of $\mathrm{OH}$ groups in the structure. The active site residues involved in the formation of hydrogen bonds were GIn57, Gly28, Asp30, Arg34, Gly346, Arg351, Thr312, Tyr409 and Leu 436 (Figure. 6 a).

Table 3: Molecular Docking Score of HPLC characterized compounds against cervical cancer targets

\begin{tabular}{|c|c|c|c|c|}
\hline $\begin{array}{l}\text { Targets/Co } \\
\text { Compounds }\end{array}$ & Piperine & Tannic Acid & Rutin & Doxorubicin \\
\hline GCR & $\begin{array}{l}-42.11 \\
\mathrm{Kcal} / \mathrm{mol}\end{array}$ & NP & $\begin{array}{l}-37.11 \\
\mathrm{Kcal} / \mathrm{mol}\end{array}$ & NP \\
\hline Her2 & $\begin{array}{l}-42.15 \\
\mathrm{Kcal} / \mathrm{mol}\end{array}$ & $\begin{array}{l}-112.53 \\
\text { Kcal/mol }\end{array}$ & $\begin{array}{l}-48.21 \\
\mathrm{Kcal} / \mathrm{mol}\end{array}$ & $-61.736 \mathrm{Kcal} / \mathrm{mol}$ \\
\hline HEXB & $\begin{array}{l}-29.74 \\
\mathrm{Kcal} / \mathrm{mol}\end{array}$ & NP & $\begin{array}{l}-35.02 \\
\mathrm{Kcal} / \mathrm{mol}\end{array}$ & $-53.905 \mathrm{Kcal} / \mathrm{mol}$ \\
\hline
\end{tabular}

\section{The ADME and Druglikeliness properties}

The in-silico ADME and druglikeliness prediction revealed that all the compounds have potential of being hERG blocker, while piperine can be hepatotoxic and may potentially have harmful reproductive effect. Also, it was observed among all the compounds tannic acid has the lowest drug score of 0.17 which is considered as very less for considering a compound as a lead molecule in clinical trials. Rutin and Tannic acid may also cause drug induced liver damage. Since results are based on a prediction model future in vivo studies are needed for validation (Table 4).

Table 4: ADME and Drug likeliness evaluation of HPLC characterized compounds. 


\begin{tabular}{|c|c|c|c|c|c|}
\hline & Molecules & Piperine & $\begin{array}{l}\text { Tannic } \\
\text { Acid }\end{array}$ & Rutin & Notes \\
\hline \multirow[t]{2}{*}{ Absorption } & $\begin{array}{l}\text { Papp (Caco-2 } \\
\text { Permeability) }\end{array}$ & $\begin{array}{l}-4.661 \\
\mathrm{~cm} / \mathrm{s}\end{array}$ & $\begin{array}{l}-6.525 \\
\mathrm{~cm} / \mathrm{s}\end{array}$ & $\begin{array}{l}-6.606 \\
\mathrm{~cm} / \mathrm{s}\end{array}$ & Optimal: higher than $-5.15 \mathrm{~cm} / \mathrm{s}$ \\
\hline & $\begin{array}{l}\text { HIA (Human } \\
\text { Intestinal } \\
\text { Absorption) }\end{array}$ & $68.5 \%$ & $19.9 \%$ & $21 \%$ & $\geq 30 \%: H I A+;<30 \%: H I A-$ \\
\hline \multirow[t]{3}{*}{ Distribution } & $\begin{array}{l}\text { PPB (Plasma } \\
\text { Protein } \\
\text { Binding) }\end{array}$ & $89.021 \%$ & $61.87 \%$ & $76.65 \%$ & $\begin{array}{l}\text { Significant with drugs that are } \\
\text { highly protein-bound and have a } \\
\text { low therapeutic index. }\end{array}$ \\
\hline & $\begin{array}{l}\text { VD (Volume } \\
\text { Distribution) }\end{array}$ & 0.579 L/Kg & $\begin{array}{l}-1.228 \\
\mathrm{~L} / \mathrm{kg}\end{array}$ & $-1.052 \mathrm{~L} / \mathrm{kg}$ & $\begin{array}{l}\text { Optimal: } 0.04-20 \mathrm{~L} / \mathrm{kg} \text {; } \\
\text { Range: }<0.07 \mathrm{~L} / \mathrm{kg} \text { : Confined to } \\
\text { blood, bound to plasma protein or } \\
\text { highly hydrophilic; } 0.07-0.7 \mathrm{~L} / \mathrm{kg} \text { : } \\
\text { Evenly distributed; >0.7L/kg: } \\
\text { Bound to tissue components (e.g., } \\
\text { protein, lipid), highly lipophilic }\end{array}$ \\
\hline & $\begin{array}{l}\text { BBB (Blood- } \\
\text { Brain Barrier) }\end{array}$ & 0.989 & 0.783 & 0.018 & $\begin{array}{l}\text { BB ratio }>=0.1 \text { : } B B B+\text {; } B B \text { ratio } \\
<0.1 \text { : BBB-These features tend to } \\
\text { improve BBB permeation: } \\
\text { H-bonds (total) }<8-10 ; \mathrm{MW}< \\
400-500 ; \text { No acids. }\end{array}$ \\
\hline \multirow[t]{10}{*}{ Metabolism } & $\begin{array}{l}\text { P450 CYP1A2 } \\
\text { inhibitor }\end{array}$ & Positive & Negative & Negative & \\
\hline & $\begin{array}{l}\text { P450 CYP1A2 } \\
\text { Substrate }\end{array}$ & Negative & Negative & Negative & \\
\hline & $\begin{array}{l}\text { P450 CYP3A4 } \\
\text { inhibitor }\end{array}$ & Positive & Negative & Positive & \\
\hline & $\begin{array}{l}\text { P450 CYP3A4 } \\
\text { substrate }\end{array}$ & Positive & Negative & Negative & \\
\hline & $\begin{array}{l}\text { P450 CYP2C9 } \\
\text { inhibitor }\end{array}$ & Negative & Negative & Negative & \\
\hline & $\begin{array}{l}\text { P450 CYP2C9 } \\
\text { substrate }\end{array}$ & Negative & Negative & Negative & \\
\hline & $\begin{array}{l}\text { P450 CYP2C19 } \\
\text { inhibitor }\end{array}$ & Negative & Negative & Negative & \\
\hline & $\begin{array}{l}\text { P450 CYP2C19 } \\
\text { substrate }\end{array}$ & Negative & Negative & Negative & \\
\hline & $\begin{array}{l}\text { P450 CYP2D6 } \\
\text { inhibitor }\end{array}$ & Positive & Positive & Negative & \\
\hline & $\begin{array}{l}\text { P450 CYP2D } 6 \\
\text { substrate }\end{array}$ & Positive & Negative & Negative & \\
\hline \multirow[t]{2}{*}{ Excretion } & $\begin{array}{l}\mathrm{T}_{1 / 2}(\text { Half Life } \\
\text { Time) }\end{array}$ & $1.483 \mathrm{~h}$ & $2.443 \mathrm{~h}$ & $2.138 \mathrm{~h}$ & $\begin{array}{l}\text { Range: >8h: high; } 3 \mathrm{~h}<\mathrm{Cl}<8 \mathrm{~h} \text { : } \\
\text { moderate; <3h: low }\end{array}$ \\
\hline & $\begin{array}{l}\text { CL (Clearance } \\
\text { Rate) }\end{array}$ & $\begin{array}{l}1.965 \\
\mathrm{~mL} / \mathrm{min} / \mathrm{kg}\end{array}$ & -1.098 & $\begin{array}{l}0.641 \\
\mathrm{~mL} / \mathrm{min} / \mathrm{kg}\end{array}$ & $\begin{array}{l}\text { Range: }>15 \mathrm{~mL} / \mathrm{min} / \mathrm{kg}: \text { high; } \\
5 \mathrm{~mL} / \mathrm{min} / \mathrm{kg}<\mathrm{Cl}<15 \mathrm{~mL} / \mathrm{min} / \mathrm{kg}: \\
\text { moderate; }<5 \mathrm{~mL} / \mathrm{min} / \mathrm{kg}: \text { low }\end{array}$ \\
\hline
\end{tabular}




\begin{tabular}{|c|c|c|c|c|c|}
\hline \multirow[t]{6}{*}{ Toxicity } & $\begin{array}{l}\text { hERG (hERG } \\
\text { Blockers) }\end{array}$ & Positive & Positive & Positive & \\
\hline & $\begin{array}{l}\text { H-HT (Human } \\
\text { Hepatotoxicity) }\end{array}$ & Positive & Negative & Negative & \\
\hline & $\begin{array}{l}\text { AMES (Ames } \\
\text { Mutagenicity) }\end{array}$ & Negative & Negative & Positive & \\
\hline & $\begin{array}{l}\text { SkinSen (Skin } \\
\text { sensitization) }\end{array}$ & Negative & Negative & Negative & \\
\hline & $\begin{array}{l}\text { LD50 (LD50 of } \\
\text { acute toxicity) }\end{array}$ & $\begin{array}{l}1184.042 \\
\mathrm{mg} / \mathrm{kg}\end{array}$ & $\begin{array}{l}1643.452 \\
\mathrm{mg} / \mathrm{kg}\end{array}$ & $\begin{array}{l}419.47 \\
\mathrm{mg} / \mathrm{kg}\end{array}$ & $\begin{array}{l}\text { High-toxicity: 1 50 mg/kg; } \\
\text { Toxicity: } 51 \sim 500 \mathrm{mg} / \mathrm{kg} \text {; low- } \\
\text { toxicity: } 501 \sim 5000 \mathrm{mg} / \mathrm{kg} \text {. }\end{array}$ \\
\hline & $\begin{array}{l}\text { DILI (Drug } \\
\text { Induced Liver } \\
\text { Injury) }\end{array}$ & Negative & Positive & Positive & \\
\hline \multirow{5}{*}{$\begin{array}{l}\text { Osiris } \\
\text { Property } \\
\text { Explorer }\end{array}$} & Mutagenic & Negative & Negative & Negative & \\
\hline & Tumorigenic & Negative & Negative & Negative & \\
\hline & Irritant & Negative & Negative & Negative & \\
\hline & $\begin{array}{l}\text { Reproductive } \\
\text { Effect }\end{array}$ & Positive & Negative & Negative & \\
\hline & Drug Score & 0.39 & 0.17 & 0.57 & $0-1$ \\
\hline
\end{tabular}

\section{Discussion}

Cervical cancer remains a burden for women of low- and middle-income countries (LMICs) such as India, South Africa, China and Brazil. Half a million new cases of cervical cancer and 311365 deaths are reported annually due to lack of effective treatment ${ }^{1}$. Currently, the recommended therapeutic regimens include chemotherapy, radiation therapy, and surgery ${ }^{10}$. However, they present several limitations including side effects or ineffectiveness. Therefore, it is important to search for new novel therapeutic agents or drug candidates that are naturally synthesized which will specifically act on the cancer cells without affecting the normal cells. Plant extracts and their bioactive compounds play a significant role in prevention of cancer and many more diseases. Phytochemicals have proved to be an excellent reservoir of polyphenols, tannins, flavonoids, alkaloids, terpenes, etc. ${ }^{11}$. Recently, more attention has been placed on tannins with the utilization of some herbs such as Phyllanthus emblica, Sanguisorba officinalis, as well as red wine with considerable tannins ${ }^{12}$. Plant-derived chemotherapeutic agents such as cisplatin, carboplatin, paclitaxel, ifosfamide, curcumin, camptothecin, taxol, and combretastatin have been used widely against cervical carcinoma ${ }^{13}$. Keeping all the above points in mind present study was designed to evaluate ethyl acetate and $70 \%$ ethanol seed extracts of $A$. precatorius obtained by different extraction methods as a potential therapy against cervical carcinoma by evaluating its antioxidant capacity and in-vitro anti-proliferative activity as well as binding affinity of its polyphenolic flavonoids (rutin) and tannins (tannic acid) against receptors mediating signaling pathways of cervical carcinoma. Here, we reported that the content of major flavonoids of $A$. precatorius was significantly higher in APE (sox) seed extract (112.7 $\pm 0.127 \mathrm{mg}$ Quercetin Equivalent/g of extract) as compared to the other extracts. Similarly, the total phenolic content in A. precatorius was higher in APA (mac) seed extract (108.53 $\pm 0.089 \mathrm{mg}$ Quercetin Equivalent/g of extract) in comparison to the other extracts. Moreover, the total tannin 
content of APA (sox) amounting to $98.98 \pm 0.011 \mathrm{mg}$ tannic acid equivalents/g of extract was higher than that of other extracts. As corroborated previously, less content of flavonoids, phenolics and tannins of $A$. precatorius have been reported. Another study by Jing et. al., reported that polarity of the solvents used for extraction plays an important role in the concentration of phenols and flavonoids ${ }^{14}$. HPLC can be used to identify, separate and quantify, phytochemicals ${ }^{15}$.The most important compounds identified in our study are polyphenolic flavonoids (rutin), tannins (tannic acid) and alkaloids (piperine). All these compounds contained in the seed extracts of $A$. precatorius may account for its antioxidant capacity. To evaluate antioxidant capacity, DPPH free radical scavenging was examined with 70\% ethanolic and ethyl acetate seed extracts where APA (sox) seed extract exhibited excellent radical scavenging activity with an IC50 value of $14.49 \pm 0.93 \mu \mathrm{g} / \mathrm{ml}$ as compare to other extracts. (Figure 2). Previously, Gul et al., observed antioxidant potential of leaf extracts of $A$. precatorius, with an IC50 value of $60.67 \pm 1.03 \mu \mathrm{g} / \mathrm{ml}^{16}$. The radical scavenging activity can be explained by different composition of each extract as there are compounds (polyphenolic flavonoids and phenolics) that react quickly with DPPH to get reduced due to the formation of nonradical ${ }^{17}$. Therefore, as corroborated by previous studies, polyphenols and tannins could be beneficial for human health, owing to their antioxidant property ${ }^{18,19}$. We have reported for the first time about the potential anticancer activity of $A$. precatorius seed extracts on Hep2c cells and its inhibitory efficacy with receptors of Human cervical carcinoma. In order to evaluate $A$. precatorius as a potential therapy for cervical cancer, all seed extracts prepared by using soxhlet \& maceration method extracts were assayed against Hep2c Cells. All seed extracts exhibited antiproliferative activity in a dose-dependent manner. However, our results revealed that the most promising extract was A. precatorius ethyl acetate seed extract (APE (mac)) which had an IC50 value $85.90 \pm 0.93 \mu \mathrm{g} / \mathrm{mL}$ in the Hep2c cell line. Previous studies on vulpinic acid reported an IC50 value $34.4 \mu \mathrm{M}$ against cervical carcinoma cell line ${ }^{20}$ which may be attributed to the type of solvents and methods of extractions used. The enzymatic activity and non-enzyme content were determined in Hep2C cells. Our current study revealed that SOD and GST activity was observed as highest in the APA(Mac) extract whereas the catalase activity and GSH content was maximum in the APE(Mac) extract. Further, the MDA content was observed to be the least in APE(Mac) extracts. Polyphenolic flavonoids, tannins and alkaloids possesses potent anticancer activities with multiple mechanisms, such as apoptosis, cell cycle arrest, and inhibition of invasion and metastases ${ }^{12}$. However, to understand the exact mechanism of specificity against cervical cancer cells, further in-depth and extensive investigations are required. The antiproliferative effect of $A$. precatorius seed extracts may be attributed to the suppression of multiple oncogenic signaling pathways and tumorpromoting factors. In this analysis, we studied the following receptors like Glucocorticoids, Her2 and HEXB known to be associated with proliferation of cervical cancer ${ }^{3-5}$. Piperine, rutin and tannic acid exhibits a myriad of medicinal benefits such as antioxidant, anti-inflammatory, anticancer and neuro-protective effects ${ }^{21-23}$. In this study, tannic acid (TA) has shown maximum binding energy against Her2 receptor rather than the standard drug doxorubicin. As far as the previous studies were concerned compounds like Tangeretin, wogonin, quercetin, and other flavonoids have shown less binding energy to the GC and Her2 receptor with respect to present studies ${ }^{24,25}$.

The present study concludes that both the extraction methods (maceration \& Soxhlet) were effective to obtain a maximum amount of biologically active phytochemicals. This information is supported by the results of HPLC of phytochemicals of the extracts and can be further use for the isolation of bioactive compounds from seeds of $A$. precatorius which might be utilized as a possible herbal remedy against restricting growth of cervical carcinoma in near future. This plant seed has promising compounds to be tested as potential anticancer and antioxidant drugs for treatment of cervical cancer. However, further investigations need to be done either to isolate the antioxidant compounds or to determine the in vivo biological activity of these extracts, cervical cancer models are needed for preclinical trials. 


\section{Methods}

\section{Chemicals}

The analytical grade chemicals were purchased from Hi-Media and Merck, India. Standard drugs were purchased from Sigma-Aldrich, India. 2,4,6-tris(2-pyridyl)-s-triazine TPTZ and MTT reagent were procured from Merck, India. Dulbecco's Modified Eagle's Medium (DMEM), fetal bovine serum (FBS) and penicillin (5000 U/mL), streptomycin (2500 U/mL) from Gibco (USA).

\section{Sample collection}

Seeds of $A$. precatorius were collected from the Khari Baoli, Kucha Challan, Chandni Chowk, Delhi complies with relevant institutional, national, and international guidelines and legislation. Voucher specimens were deposited at Raw Material Herbarium and Museum, Delhi (RHMD), India and were authenticated by Dr. Sunita Garg, (Emeritus Scientist, CSIR-NISCAIR), with Ref No: NISCAIR/RHMD/Consult/2020/3697-98-2.

\section{Genomic DNA isolation and molecular identification}

Genomic DNA was isolated from seeds of $A$. precatorius using Cetyltrimethylammonium bromide (CTAB) method ${ }^{26}$. The genomic DNA was amplified using rbcLa-forward primer (ATGTCACCACAAACAGAGACTAAAGC) and $r b c L a-$ reverse primer (GTAAAATCAAGTCCACCRCG). PCR amplification was carried out in Veriti model of Applied Biosystem Thermo cycler 27.

\section{Cell culture}

Human cervix carcinoma Hep2C cell line was obtained from National Centre for Cell Sciences (NCCS), Pune, India. The cells were cultured in Dulbecco's modified Eagle's medium (DMEM) supplemented with 10\% (v/v) FBS, $100 \mathrm{U} / \mathrm{ml}$ penicillin, and $100 \mu \mathrm{g} / \mathrm{mL}$ streptomycin at $37^{\circ} \mathrm{C}$ in a humidified atmosphere of $5 \% \mathrm{CO}_{2}$.

\section{Preparation of Extracts}

Seeds were washed with distilled water to remove dirt and soil particles, followed by drying and grinding to form powder and used throughout the study.

\section{Soxhlet Extraction Method}

Alcoholic extracts were prepared by soxhlet method using ethyl acetate and $70 \%$ ethanol as solvent. $10 \mathrm{~g}$ of seed powder was placed inside a thimble made from thick filter paper and loaded into the soxhlet extractor. The Soxhlet extractor was placed onto the flask containing the solvent $(500 \mathrm{~mL})$ equipped with a condenser. The extractor was then allowed to heat to reflux for $16 \mathrm{~h}$ at $70{ }^{\circ} \mathrm{C}$. Extracts were filtered twice through a Whatman No. 1 paper filter and concentrated to the dry mass with the aid of rotary evaporator ${ }^{28}$.

\section{Maceration Extraction Method.}

$10 \mathrm{~g}$ of seed powder was dissolved in $100 \mathrm{ml}$ of solvent (Ethyl acetate and $70 \%$ Ethanol) and then kept in the dark for 7 days at room temperature. The conical flasks of the extract were covered with cotton plugs to avoid the evaporation. After 7 days of incubation, they were filtered with muslin cloth followed by Whatman No.1 filter paper and concentrated to the dry mass with the aid of rotary evaporator ${ }^{29}$. 
The dried extracts were dissolved in absolute dimethyl sulfoxide (DMSO) as $50 \mathrm{mg} / \mathrm{mL}$ and diluted with phosphatebuffered saline (PBS, pH 7.4) to give final concentrations.

\section{Quantification of Phytochemical Constituents}

Total flavonoid content was measured by Aluminium Chloride Spectrophotometric method. Absorbance was measured against the prepared blank at $510 \mathrm{~nm}$ and results were represented as quercetin equivalents (mg QE)/g of extract. Similarly, total phenolic content and total tannins content was quantified by Folin-Ciocalteau method. Absorbance of mixture was measured at $725 \mathrm{~nm}$. Final results were represented as quercetin equivalents (mg QE)/g of extract and tannic Acid equivalents (mg QE)/g of extract, respectively ${ }^{28,30,31}$. All the concentrations were calculated using a standard calibration plot.

\section{Antioxidant Assay}

Antioxidant potential in the seed extracts was determined by electron transfer assay i.e. (2,2-Diphenyl-1picrylhydrazyl) Radical scavenging assay (DPPH) and Ferric reducing antioxidant power (FRAP) assay. DPPH free radical scavenging assay was performed to measure the hydrogen donating or radical scavenging ability. Briefly, $0.04 \mathrm{mM}$ DPPH radical solution was prepared in methanol and then $900 \mu \mathrm{L}$ of this solution was mixed with $100 \mu \mathrm{L}$ of extract solution containing different concentrations of seed extracts. The absorbance was measured at $517 \mathrm{~nm}$ after 30 min of incubation. Methanol (95\%), DPPH solution and were used as blank, and control respectively. Quercetin was used as the standard.50\% inhibitory concentrations (IC50 values) of the extracts were calculated from graph as concentration versus percentage inhibition. Radical scavenging activity was expressed as percentage of inhibition.

Measurements were taken in triplicate. The IC50 of the extract and standards were determined graphically ${ }^{32}$.

The percentage of inhibition was calculated by using the formula:

\section{Percentage of inhibition $=[($ absorbance of control- absorbance of reaction mixture $) /$ absorbance of control $] \times 100$}

Further for the FRAP assay, FRAP reagent solution was prepared with $300 \mathrm{mM}$ sodium acetate buffer (pH 3.6), $10 \mathrm{mM}$ 2,4,6-tris(2-pyridyl)-s-triazine (TPTZ) in $40 \mathrm{mM} \mathrm{HCl}$ and $20 \mathrm{mM} \mathrm{FeCl}_{3} \cdot 6 \mathrm{H}_{2} \mathrm{O}(10: 1: 1 \mathrm{v} / \mathrm{v} / \mathrm{v})$. The absorbance was measured at $593 \mathrm{~nm}$ after a $30 \mathrm{~min}$ incubation at room temperature against $50 \%$ ethanol as blank. A calibration curve was prepared using FeSO4x 7H2O. FRAP activity was expressed as mM Fe (II)/ g dry weight of extract ${ }^{28,33,34}$.

\section{High Pressure Liquid Chromatography}

The presence of phenolic compounds and alkaloids in the prepared extracts was screened against standards rutin, tannic acid and piperine by HPLC. The analysis was performed using a C-18 reversed phase column (Phenomenex, Gemini $5 \mu, 250 \mathrm{~mm}$ length $\times 4.6 \mathrm{~mm}$ internal diameter). The mobile phase consisted of methanol: $0.1 \%$ orthophosphoric acid (77:23) for quercetin, methanol: water (50:50) for tannic acid and $1 \%$ acetic Acid: acetonitrile (52:48) for piperine were chosen for the separation at a constant flow rate of $1 \mathrm{~mL} / \mathrm{min}$. The column temperature was set to $38^{\circ} \mathrm{C}$ and the injection volume was $20 \mu \mathrm{L}$. The wavelengths were set to $370 \mathrm{~nm}$ for the detection of rutin, 280 $\mathrm{nm}$ for tannic acid, and 343nm for piperine. Retention time was observed by using HPLC ${ }^{28,35}$.

\section{Antiproliferative activity}

Cytotoxic activity of $A$. precatorius seed extracts on Hep2C cells were determined by using a modified 3-(4, 5dimethylthiazol-2-yl)-2, 5-diphenyltetrazolium (MTT) assay. Briefly, Hep2c cells were seeded ( $1 \times 10^{4}$ cells/well) onto flat-bottomed 96-well culture plates. Further, different concentrations of seed extracts and doxorubicin (standard)were 
added to each well. After $48 \mathrm{~h}$ of incubation $10 \mu \mathrm{l}$ of MTT reagent $(5 \mathrm{mg} / \mathrm{ml})$ were added and mixtures were reincubated for $4 \mathrm{~h}$. The resulting formazan was solubilized with DMSO $(100 \mu \mathrm{l})$. Finally, the absorbance of formazan was measured at $570 \mathrm{~nm}$ using an automated microplate reader (Bio-Rad, Illinois, USA). Experiments were carried out in triplicates. The cytotoxicity was recorded as concentration causing 50\% growth inhibition (IC50) for cell line ${ }^{36}$.

The percent inhibition was calculated by using the following formula:

\%Inhibition $=100-($ mean OD of test compound-mean OD of negative control) $/$ (mean OD of positive control mean OD of negative control) $\times 100$

\section{Antioxidant Enzyme Activity Assay on Hep2C cells}

To estimate the effect of $A$. precatorius seed extracts on Hep2C cells, the enzymatic activity [superoxide dismutase (SOD), catalase (CAT), Glutathione-S-Transferase (GST)] and non-enzyme content [Glutathione content (GSH) and lipid peroxidation (Malondialdehyde (MDA) content)] were evaluated. A total of $1.51 \times 10^{5}$ cells/well were seeded in 24 well plates and incubated for $24 \mathrm{~h}$ in a $\mathrm{CO}_{2}$ incubator at $37^{\circ} \mathrm{C}$ followed by a $48 \mathrm{~h}$ treatment with the obtained IC50 specific values of each of these extracts. The cells were harvested by washing with PBS followed by trypsinization. Further, the samples were centrifuged at $10,000 \mathrm{rpm}$ for $20 \mathrm{~min}$ at $4^{\circ} \mathrm{C}$ to obtain the cell lysate which was further used for estimation of enzyme and non-enzyme content in accordance with standardized procedures ${ }^{37}$.

\section{Molecular Docking and MM-GBSA refinement}

The molecular docking was performed on cervical cancer targets using molecules found in HPLC. The X-ray crystallographic structures of targets were obtained from Protein Data Bank (https://www.rcsb.org/search) using PDB ID:3LMY (HEXB), 5MY6(4LSJ), and HER2 (5MY6). Molecular docking was performed using Schrödinger Maestro Suite 2020-3 (Schrödinger, LLC, New-York, NY) ${ }^{38,39}$. All the structures were optimized prior to docking, any structural inconsistencies were rectified using Schrodinger's in-built protein preparation wizard module. HEX-B and GCR both have co-crystallized ligands which were chosen to act as the center of the receptor grid. In case of HER2 active site prediction was made using SiteMap module, active sites with a score $<0.9$ were rejected. The internal grid size $x^{\star} y^{\star} z$ was fixed $155^{\star} 15 \star 15 \AA$. Further, MM-GBSA refinements were carried out on the docked poses of each isoform with a flexible residue distance of $5.0 \AA$.

\section{ADMET Analysis and Drug Score}

The computational ADME/TOX analysis for identified compounds for 23 molecular descriptors were computed using ADMETLAB (http://admet.scbdd.com/) ${ }^{40}$. Additional Descriptors like mutagenic and drug score were computed using Osiris Property Explorer ${ }^{41}$.

\section{Statistical analysis}

The statistical data were represented as mean \pm standard deviation. Statistical analysis was performed using oneway analysis of variance (ANOVA). A probability value of $\leq 0.05$ was considered as statistically significant. All analyses were performed using IBM-SPSS statistical software (version 13.0).

\section{Abbreviations}

APE (sox): ethyl acetate extract soxhlet; APA (mac): 70\% ethanol extract maceration; APA (sox): 70\% ethanol extract soxhlet; APE (mac): ethyl acetate extract maceration; MTT assay: 3-(4,5-dimethylthiazol-2-yl)-2,5-diphenyl-2H- 
tetrazolium bromide; SOD: Superoxide dismutase; CAT: Catalase; GST: Glutathione s transferase; GSH: Glutathione; MDA: Malondialdehyde.

\section{Declarations}

\section{Acknowledgement}

The authors acknowledge Amity University, Noida, Uttar Pradesh, India for providing infrastructure and support.

\section{Author Contribution}

Kumud Bala: Conceptualization, Methodology, Supervision. Amritpal Kaur. Experimental, Analysis, Writing- Original draft preparation, Methodology, Investigation. Yash Sharma: Visualization, Investigation. Kamran Waidha: Software, Statistical analysis, Bioinformatics, Validation. Madhumita P Ghosh: Writing- Reviewing, Editing, Supervision. Anoop Kumar: Statistical analysis, Validation

\section{Consent for Publication}

Not Applicable

\section{Data availability}

All data are available in the manuscript

\section{Data repositories}

Not applicable

\section{Conflict of Interest}

The authors declare that they have no conflicting or competing interests.

\section{References}

1. Stelzle, D. et al. Estimates of the global burden of cervical cancer associated with HIV. The Lancet Global Health 9, e161-e169 (2021).

2. Safaeian, M., Solomon, D. \& Castle, P. E. Cervical Cancer Prevention-Cervical Screening: Science in Evolution. Obstetrics and Gynecology Clinics of North America vol. 34 739-760 (2007).

3. Gutiérrez-Hoya, A. et al. Cervical cancer cells express markers associated with immunosurveillance. Journal of Immunology Research 2019, (2019).

4. Kost, B. P. et al. Glucocorticoid receptor in cervical cancer: an immunhistochemical analysis. Archives of gynecology and obstetrics 299, 203-209 (2019).

5. Li, X. Y. \& Wang, X. The role of human cervical cancer oncogene in cancer progression. International Journal of Clinical and Experimental Medicine vol. 8 8363-8368 (2015).

6. Newman, D. J. \& Cragg, G. M. Natural Products as Sources of New Drugs over the Nearly Four Decades from 01/1981 to 09/2019. Journal of Natural Products 83, 770-803 (2020).

7. Mut-Salud, N. et al. Antioxidant Intake and Antitumor Therapy: Toward Nutritional Recommendations for Optimal Results. Oxidative Medicine and Cellular Longevity (2016) doi:10.1155/2016/6719534. 
8. Mukhopadhyay, S. et al. Abrus agglutinin suppresses human hepatocellular carcinoma in vitro and in vivo by inducing caspase-mediated cell death. Acta Pharmacologica Sinica 35, 814-824 (2014).

9. Garaniya, N. \& Bapodra, A. Ethno botanical and Phytophrmacological potential of Abrus precatorius L.: A review. Asian Pacific Journal of Tropical Biomedicine S27-S34 (2014) doi:10.12980/APJTB.4.2014C1069.

10. Yang, J., Cai, H., Xiao, Z. X., Wang, H. \& Yang, P. Effect of radiotherapy on the survival of cervical cancer patients: An analysis based on SEER database. Medicine (United States) 98, (2019).

11. Matowa, P. R., Gundidza, M., Gwanzura, L. \& Nhachi, C. F. B. A survey of ethnomedicinal plants used to treat cancer by traditional medicine practitioners in Zimbabwe. BMC Complementary Medicine and Therapies 20, 113 (2020).

12. Cai, Y. et al. Recent Advances in Anticancer Activities and Drug Delivery Systems of Tannins. Medicinal Research Reviews vol. 37 665-701 (2017).

13. Wang, S. et al. Plants and cervical cancer: an overview. Expert opinion on investigational drugs 22, 1133-1156 (2013).

14. Jain, A., Sinha, P., Jain, A. \& Vavilala, S. Estimation of flavonoid content, polyphenolic content and antioxidant potential of different parts of Abrus precatorius (L.). International Journal of Pharmacy and Pharmaceutical Sciences 7, 157-163 (2015).

15. Mizzi, L., Chatzitzika, C., Gatt, R. \& Valdramidis, V. HPLC Analysis of Phenolic Compounds and Flavonoids with Overlapping Peaks. Food Technology and Biotechnology 58, 12 (2020).

16. Gul, M. Z., Ahmad, F., Kondapi, A. K., Qureshi, I. A. \& Ghazi, I. A. Antioxidant and antiproliferative activities of Abrus precatorius leaf extracts - an in vitro study. BMC Complementary and Alternative Medicine 13, (2013).

17. Tsimogiannis, D. I. \& Oreopoulou, V. Free radical scavenging and antioxidant activity of 5,7,3',4'-hydroxysubstituted flavonoids. Innovative Food Science and Emerging Technologies 5, 523-528 (2004).

18. Fanta Yadang, S. A. et al. Quantification of Bioactive Compounds and Evaluation of the Antioxidant Activity of Carissa edulis Valh (Apocynaceae) Leaves. Scientific World Journal (2019) doi:10.1155/2019/7549620.

19. Vauzour, D., Rodriguez-Mateos, A., Corona, G., Oruna-Concha, M. J. \& Spencer, J. P. E. Polyphenols and human health: Prevention of disease and mechanisms of action. Nutrients vol. 21106-1131 (2010).

20. Kiliç, N. et al. Evaluation of in vitro anticancer activity of vulpinic acid and its apoptotic potential using gene expression and protein analysis. Indian Journal of Pharmaceutical Education and Research 52, 626-634 (2018).

21. Ashafaq, M., Tabassum, H. \& Parvez, S. Modulation of Behavioral Deficits and Neurodegeneration by Tannic Acid in Experimental Stroke Challenged Wistar Rats. Molecular neurobiology 54, 5941-5951 (2017).

22. Ganeshpurkar, A. \& Saluja, A. K. The Pharmacological Potential of Rutin. Saudi Pharmaceutical Journal 25, 149164 (2017).

23. Qu, H., Lv, M. \& Xu, H. Piperine: Bioactivities and Structural Modifications. Mini-Reviews in Medicinal Chemistry 15, 145-156 (2015).

24. Austin, J. R. et al. Baicalein Is a Phytohormone that Signals Through the Progesterone and Glucocorticoid Receptors. Hormones and Cancer 11, 97-110 (2020).

25. Widowati, W. et al. Dietary flavonoids against various breast cancer subtypes: A molecular docking study. ScienceAsia 45, 452-457 (2019).

26. Li, J., Wang, S., Yu, J., Wang, L. \& Zhou, S. A Modified CTAB Protocol for Plant DNA Extraction. Chinese Bulletin of Botany 48, 72 (2013). 
27. Dong, W. et al. Discriminating plants using the DNA barcode rbcLb: An appraisal based on a large data set. Molecular Ecology Resources 14, 336-343 (2014).

28. Sharma, Y. et al. Preclinical assessment of stem of Nicotiana tabacum on excision wound model. Bioorganic Chemistry 109, 104731 (2021).

29. Sharma, Y., Nagar, A. \& Shukla, S. Antimicrobial activity and phytochemical screening of Adenium obesum (Desert rose) leaf. International Journal of Pharma and Bio Sciences 6, P85-P92 (2015).

30. Sharma, Y. et al. In vitro antioxidant activity of defatted seed extracts of Ocimum sanctum on rat PC-12 cells and its inhibitory efficacy with receptors of oral squamous cell carcinoma. Industrial Crops and Products 154, 112668 (2020).

31. Sharma, Y., Dua, D., Nagar, A. \& Srivastava, NS. Antibacterial activity, phytochemical screening and antioxidant activity of stem of Nicotiana tabacum. International journal of pharmaceutical sciences and research 7, 1156(2016).

32. Ho, K. Y., Tsai, C. C., Chen, C. P., Huang, J. S. \& Lin, C. C. Screening of Brazilian plant extracts for antioxidant activity by the use of DPPH free radical method. Phytotherapy Research 15, 127-130 (2001).

33. Benzie, I. F. F. \& Strain, J. J. Ferric reducing/antioxidant power assay: Direct measure of total antioxidant activity of biological fluids and modified version for simultaneous measurement of total antioxidant power and ascorbic acid concentration. Methods in Enzymology 299, 15-27 (1999).

34. Sharma, Y., Srivastava, N. \& Bala, K. Antioxidant and Antimicrobial Activity of Protein-AgNPs from the Stem of Nicotiana Tabacum. Current Bioactive Compounds 17, (2020).

35. Sharma, Y., Srivastava, N. \& Bala, K. Antioxidant and Antimicrobial activity of Protein-AgNPs of Stem of Nicotiana tabacum. Current Bioactive Compounds 16, (2020).

36. Taş, A. et al. An in vitro study of cytotoxic activity of euphorbia macroclada boiss on MCF-7 cells. Indian Journal of Pharmaceutical Education and Research 52, S119-S123 (2018).

37. Sharma, Y. et al. In vitro antioxidant activity of defatted seed extracts of Ocimum sanctum on rat PC- 12 cells and its inhibitory efficacy with receptors of oral squamous cell carcinoma. Industrial Crops and Products 154, 112668 (2020).

38. Salam, N. K., Adzhigirey, M., Sherman, W., Pearlman, D. A. \& Thirumalai, D. Structure-based approach to the prediction of disulfide bonds in proteins. in Protein Engineering, Design and Selection vol. 27 365-374 (Oxford Academic, 2014).

39. Zhu, K. et al. Antibody structure determination using a combination of homology modeling, energy-based refinement, and loop prediction. Proteins: Structure, Function and Bioinformatics 82, 1646-1655 (2014).

40. Dong, J. et al. Admetlab: A platform for systematic ADMET evaluation based on a comprehensively collected ADMET database. Journal of Cheminformatics 10, 1-11 (2018).

41. Rashid, M. Design, synthesis and ADMET prediction of bis-benzimidazole as anticancer agent. Bioorganic Chemistry 96, (2020).

\section{Figures}




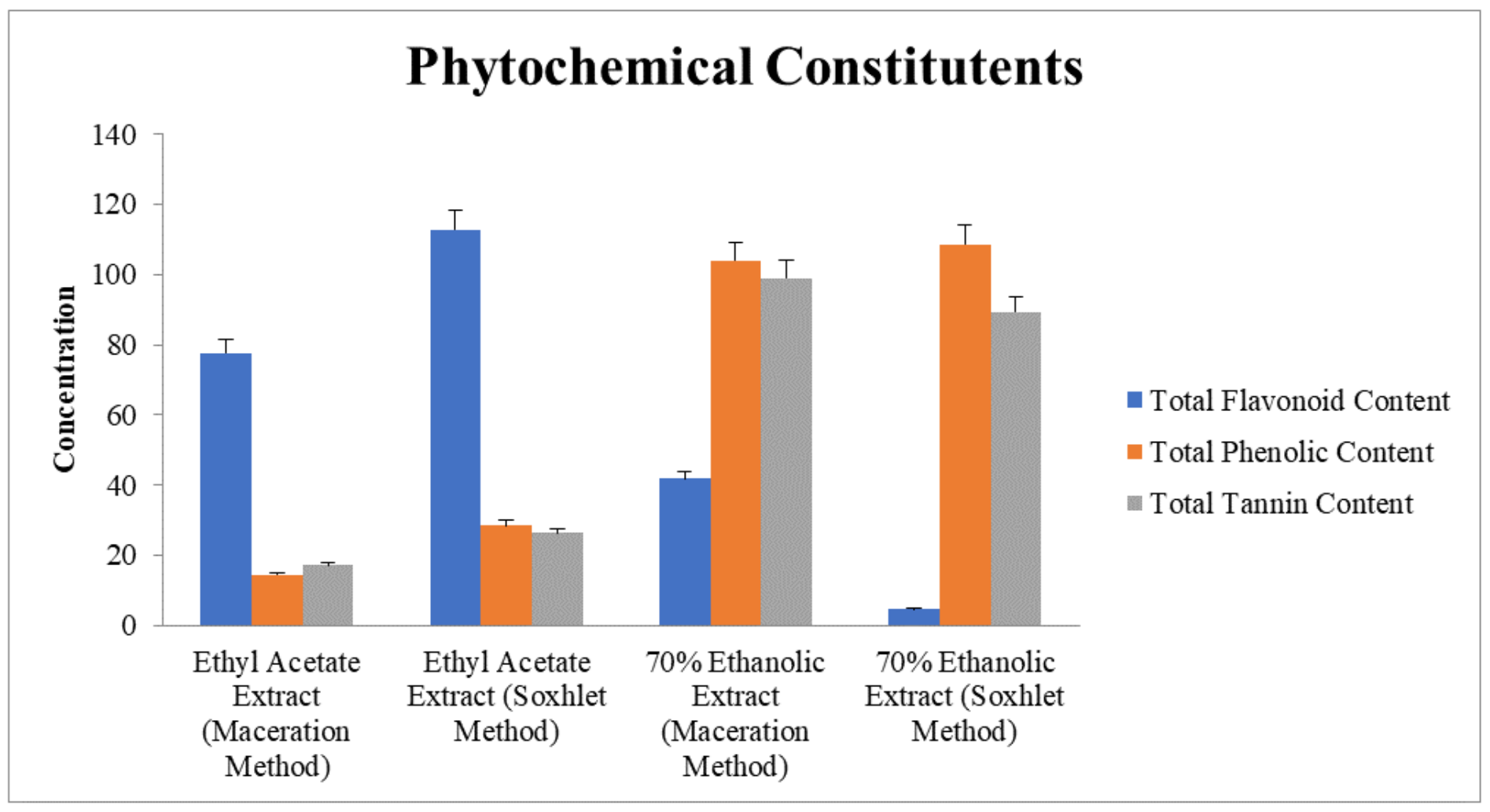

Figure 1

Comparative quantitative analysis of phytochemical constituents presents in $70 \%$ ethanol and ethyl acetate seed extracts prepared from soxhlet and maceration extraction methods. 
a.

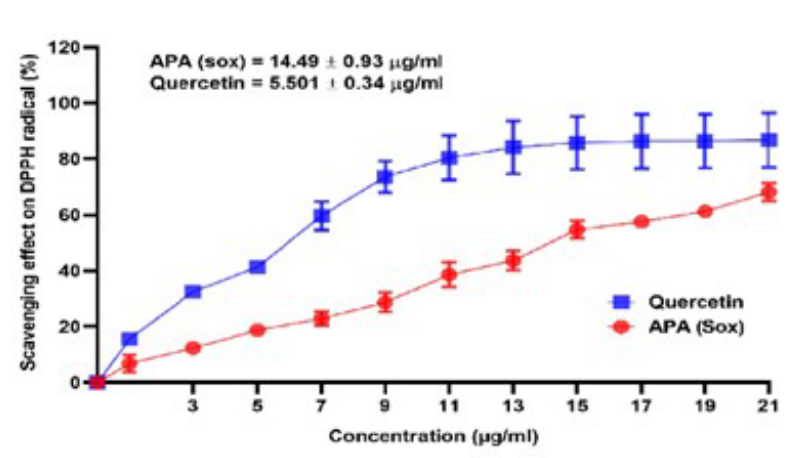

c.

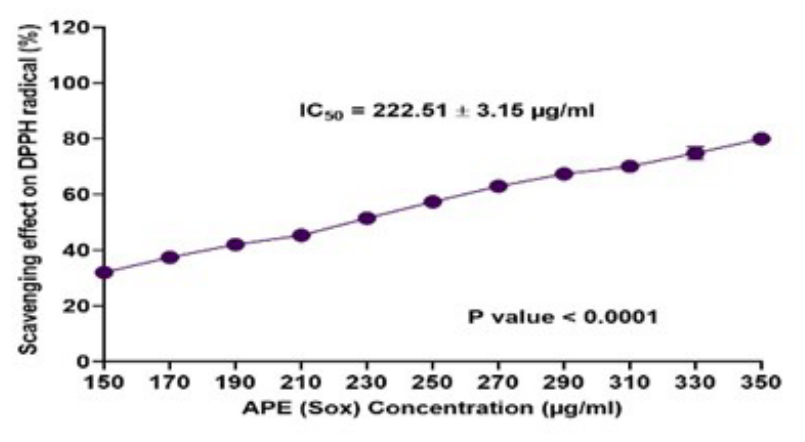

b.

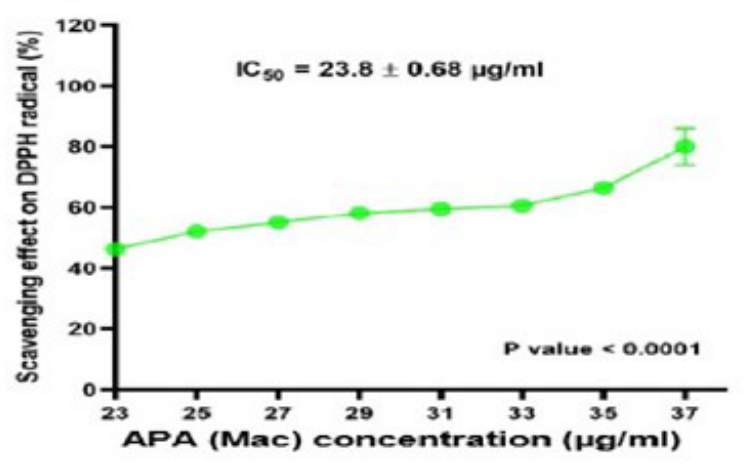

d.

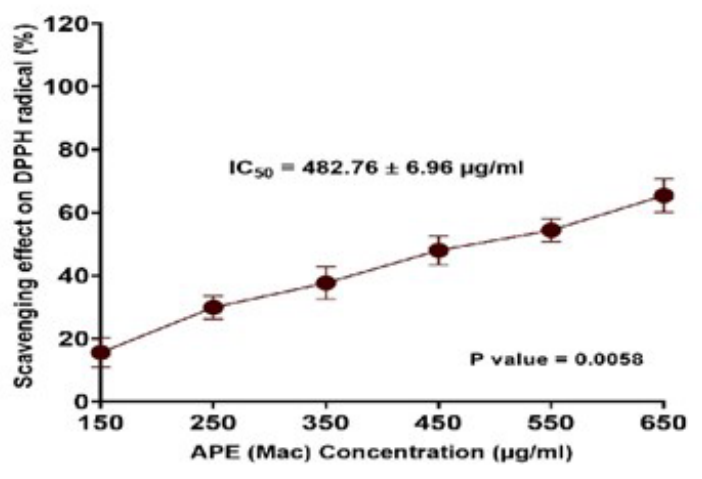

e.

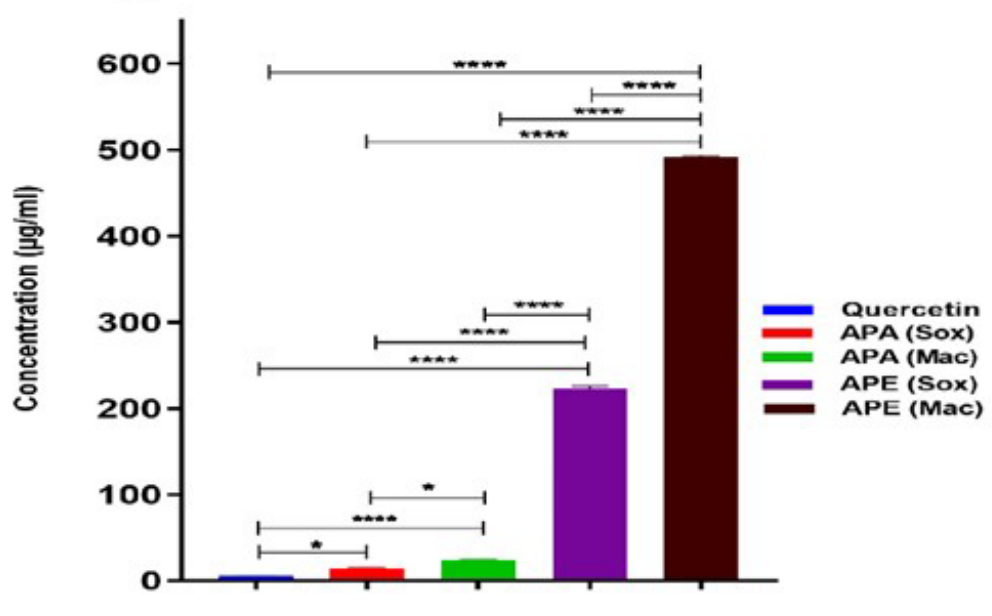

Figure 2

DPPH radical-scavenging activities of $A$. precatorius seed extracts at different concentrations: (a)Quercetin, and APA (sox), (b) APA (mac), (c) APE (sox), (d) APE (mac) (e) Comparative statistical significance between the seed extracts (APA (sox), APA (mac), APE (sox), APE (mac) and Quercetin. * $\mathrm{p}<0.05$,

$\star \star p<0.005, * \star * p<0.0005, * \star \star \star p<<0.00005$ 

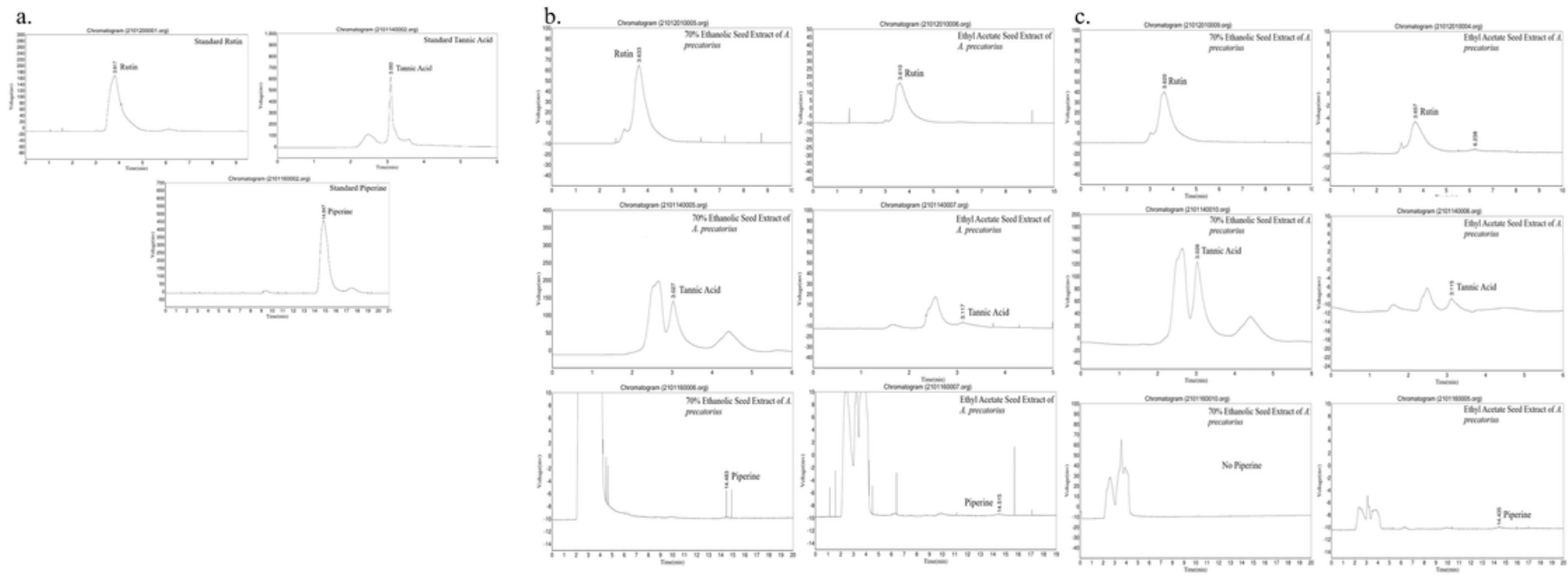

\section{Figure 3}

HPLC Chromatograms of (a.) standards: tannic acid, rutin and piperine, (b.) $70 \%$ ethanolic and ethyl acetate seed extracts of $A$. precatorius prepared from soxhlet extraction method showing rutin, tannic acid and piperine and (c.) $70 \%$ ethanolic and ethyl acetate seed extracts of $A$. precatorius prepared from maceration extraction method showing rutin, tannic acid and piperine.

a.



c.

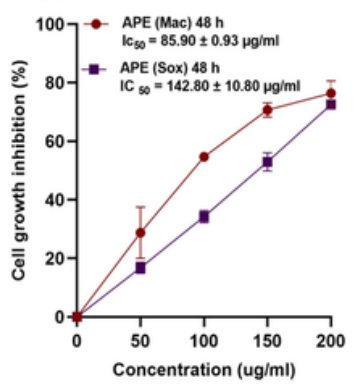

b.

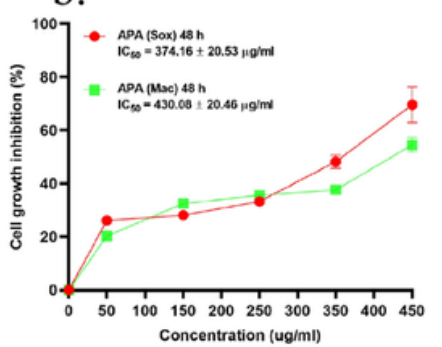

d.

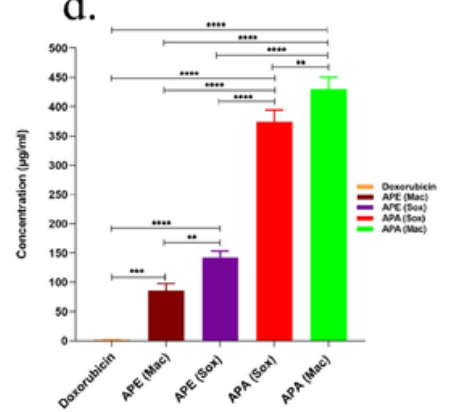

e.

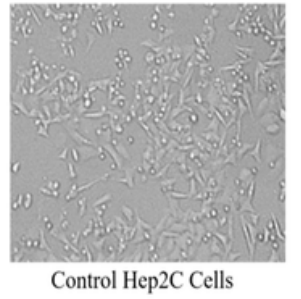

h.

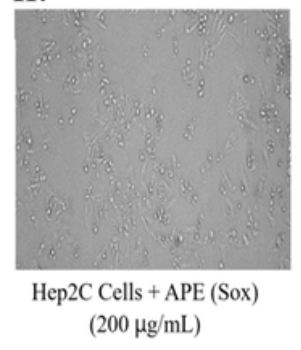

f.

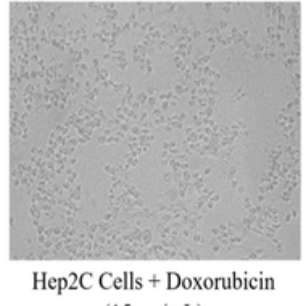

$(15 \mu \mathrm{g} / \mathrm{mL})$

i.

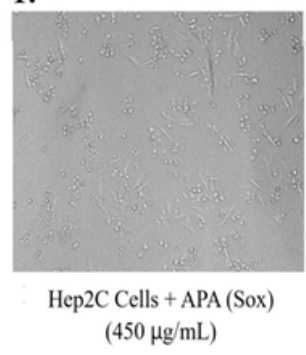

g.

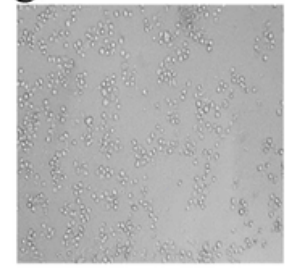

Hep2C Cells + APE (Mac) $(200 \mu \mathrm{g} / \mathrm{mL})$

$\mathrm{j}$.

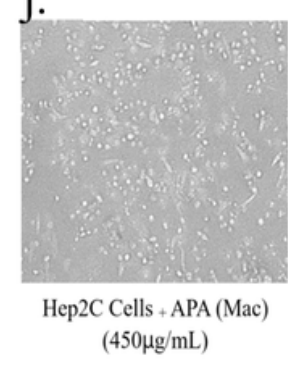

\section{Figure 4}

Antiproliferative activity of doxorubicin (standard) and A. precatorius seed extracts against Hep2C Cells using MTT assay after 48hr of treatment. (a.) doxorubicin, (b.) APA (sox) and APA (mac), (c.) APE (mac) and APE (sox). (d.) Comparative statistical significance between the extracts (APA (sox), APA (mac), APE (sox), APE (mac) and doxorubicin. Pictorial representation of Hep2C Cells under inverted light microscope using 10X objective lens (magnification 100X) after 48h exposure of doxorubicin and A. precatorius seed extracts. From 'e.' to 'j.' where (e.) 
control Hep2C Cells (Untreated), (f.) Hep2C cells treated with doxorubicin, (g.-h.) Hep2C cells treated with APE (mac); APE (sox) and, (i.j.) Hep2C cell treated with APA (sox); APA (mac). ${ }^{*} p<0.05,{ }^{*} p<0.005,{ }^{* \star *} p<0.0005,{ }^{* \star * *} p<0.00005$
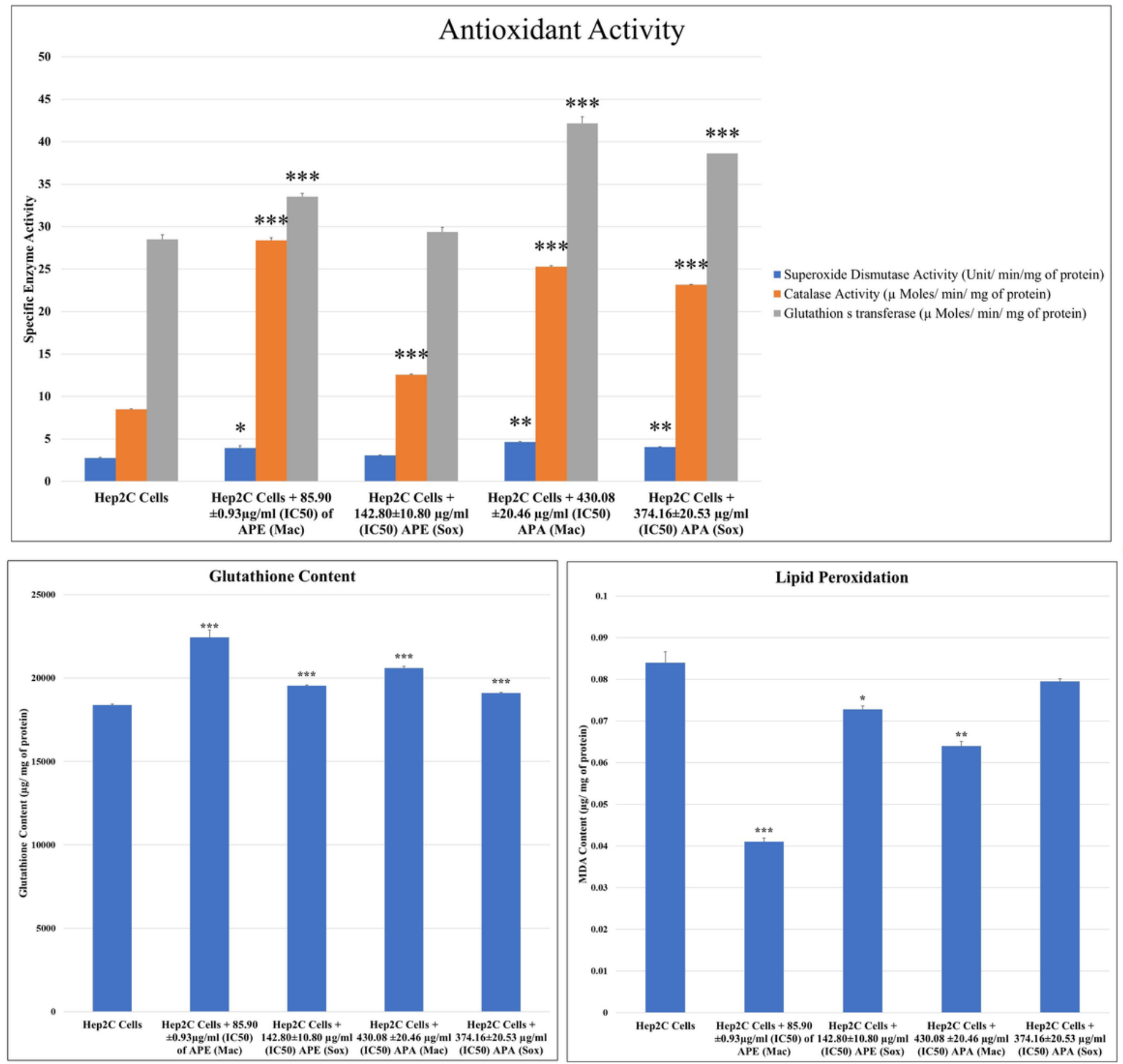

\section{Figure 5}

Antioxidant activity $A$. precatorius seed extracts in Hep2C cells on the enzyme (SOD, CAT \& GST) and non-enzyme content (GSH and MDA). The data is representative of 3 consecutive experiments. ${ }^{\star} P<0.0 .5,{ }^{\star *} \mathrm{P}<0.01$, ${ }^{\star \star *} \mathrm{P}<0.001$ 

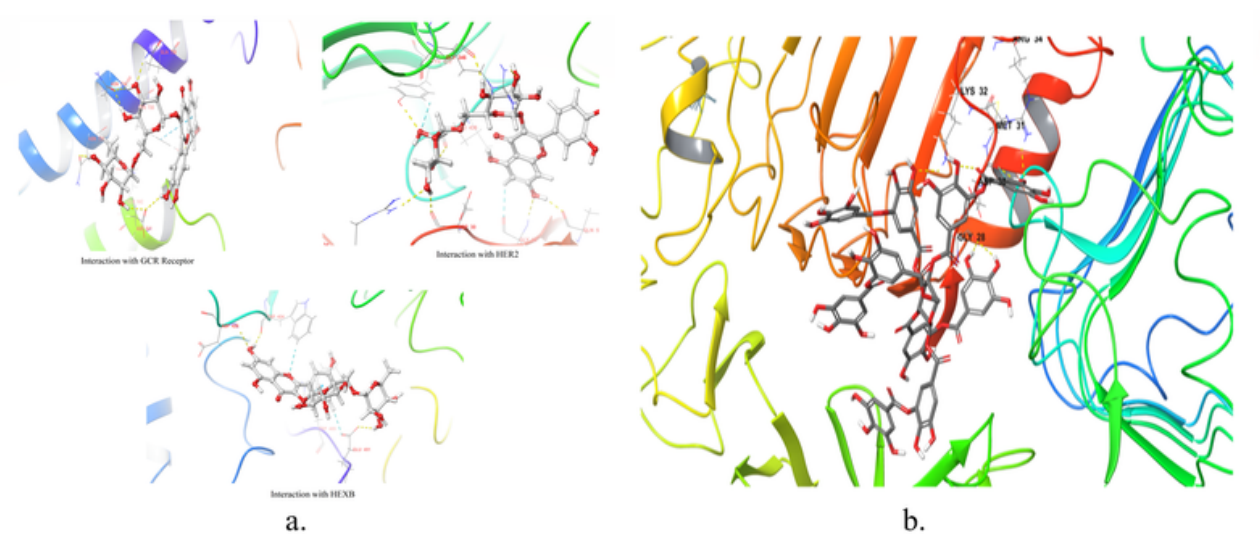

b.

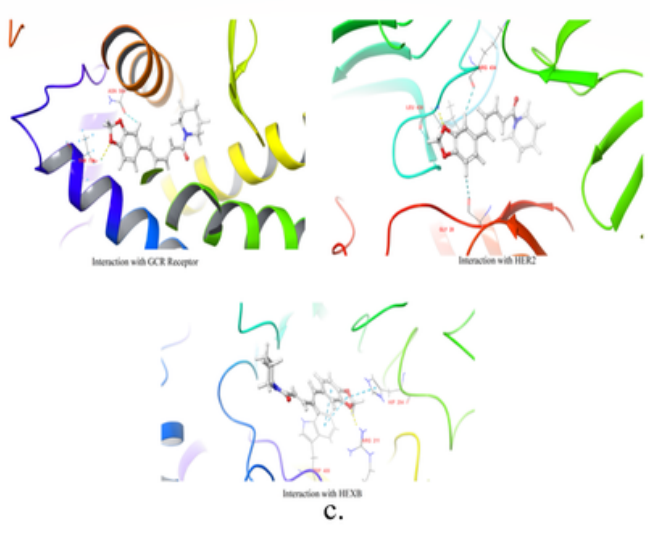

Figure 6

Molecular docking of (a.) Rutin, (b.) Tannic acid, (c.) Piperine and their interaction with amino acids of GCR receptor, HER2 receptor and HEXB receptor of cervical carcinoma.

\section{Supplementary Files}

This is a list of supplementary files associated with this preprint. Click to download.

- Supplementaryrevised.docx 